\title{
First-Year Students' EFL Reading Difficulties at a Greek Merchant Marine Academy: An Activity Theory Perspective
}

\author{
Emmanouela Seiradakis ${ }^{1,2}$ \\ ${ }^{1}$ School of Education, University of Crete, Rethimno, Greece \\ ${ }^{2}$ Language Center, Technical University of Crete, Chania, Greece \\ Correspondence: Emmanouela Seiradakis, Language Center, Kounoupidiana Campus, Technical University of \\ Crete, Chania 73100, Greece. E-mail: eseiradakis@isc.tuc.gr
}

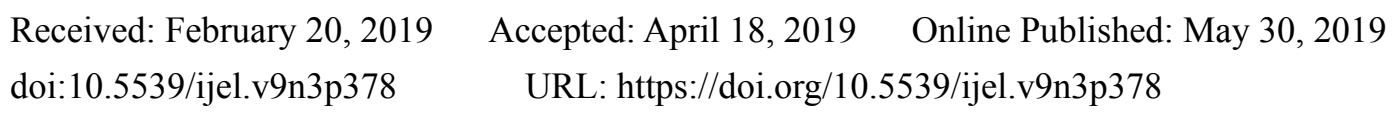

\begin{abstract}
This paper explores how the transition from secondary to tertiary education influences Greek marine engineering students' EFL reading behaviors and strategies from an activity-theory perspective. Data were gathered through individual semi-structured interviews with four first-year students who struggled with reading texts in English. Findings suggest that these students experience difficulties in reading lengthy discipline-specific texts such as technical manuals due to the fact they still use the same EFL reading strategies and have the same expectations they had before entering tertiary education. From an activity theory perspective, these students' difficulties are associated with two distinct EFL reading activity systems which have diverse goals, tools, values, and division of labour. The first system is placed within the wider Greek foreign language education context these students belonged in high school. The second, involves the system that emerged after they entered the Merchant Marine Academy as tertiary education students. These two EFL reading systems clash and create obstacles in their discipline-specific reading which in turn slows down their disciplinary socialization in the marine engineering community.
\end{abstract}

Keywords: Maritime English, reading difficulties, activity system, tertiary education

\section{Introduction}

The transition between secondary and tertiary education generates challenges for undergraduate students which may relate to "a cultural shift between different assumptions and values held about reading and writing" (Harklau, 2001, p. 34) rather than the actual cognitive difficulty of academic literacy. In the case of academic reading, this shift may generate additional discomforting experiences for novice readers in tertiary education settings where the medium of instruction is other than English but students are required to read extensive English bibliographies (Spector-Cohen et al., 2001). Due to these new academic requirements these students are suddenly forced to experience an additional transition, that is, an English academic reading transition from "learning to read" English to "reading to learn" from a range of academic genres (Grabe \& Stoller, 2013). Academic and professional genres such as research articles, authentic technical manuals and reports seem to pose significant challenges to undergraduate students across engineering, medical and science disciplines (Bitran et al, 2012; Murray, 2014; Seiradakis \& Spantidakis, 2018a; Shen, 2013).

Previous works focusing in exploring novices' academic reading difficulties in English as a Foreign Language (EFL) contexts have mostly adopted a cognitive-oriented approach undermining the sociocultural context where learning takes place despite the fact that research findings have provided solid evidence academic reading strategies are influenced by the students' academic and cultural backgrounds. This type of sociocultural reading research done with tertiary education students, perhaps unsurprisingly, has mostly investigated the reading experiences of international students, in L1 settings such as the US, Canada, Australia and the UK (Liu, 2015). Studies conducted in EFL contexts are scarce and previous works within the Greek higher education context-to the best of my knowledge-are non-existent. In an attempt to bridge this gap, this paper presents the qualitative facet of a larger study that aimed to explore the English reading difficulties of 1 st year marine engineering students at the Merchant Marine Academy of Crete, Greece from an activity theory perspective. Accordingly, my guiding research question is: 
How does the transition from secondary to tertiary education affect Greek marine engineering students' EFL reading approach?

\subsection{Theoretical Framing}

The present study draws on activity theory, a branch of Vygotskian Sociocultural Theory (SCT). Activity theory is a psychological theory which was developed by Vygotsky and his colleagues Leont'ev and Luria. In essence, activity theory, is designed to describe the purposeful actions of an individual or a group and how these actions are connected dynamically within the environment they occur. The term "activity system" is used as the unit of analysis to indicate the minimum suitable framework within which individual actions and thoughts are integrated into a meaningful manner. The "activity" can be defined as a constructed system within which the cognitive system, the behavior and the motives are integrated and organized towards achieving a specific goal. This unit creates a system which consists of the subjects (person or persons), the goal, and the common tools. Placing these elements in a wider framework facilitates their effective interpretation (Spantidakis, 2010).

Engeström (1987) further systemized activity theory with his triangular framework which zooms in a specific sociocultural context within which actions are integrated, exemplifying the interrelationships amongst them with arrows. The framework includes the six basic elements of an activity system: subjects/agents, object, tools, community and the division of labour. The subjects/agents refer to the people who are actually involved in the activity system. The object/outcome includes the purposeful actions and the goals the subjects set. It should be noted that the object is the activity's central goal and the whole activity focuses on it. Ultimately, the object leads to an outcome which is the end result of the activity system. The tools encompass all the materials, the socially constructed artefacts, thinking techniques and strategies, or other people the subjects use in order to achieve their goal/object. The community, refers to the social relations of the system. It consists of individuals who share the common object/goal and who see themselves as separate entities from other communities. Consequently, the community element implies that an activity takes place within a specific sociocultural and historical context, in other words it is the actual environment subjects operate. The rules account for the regulations, the conventions and the norms that govern a system and which the subjects must follow so as to integrate in a specific community. Lastly, the division of labour reflects how the object of the activity is related to the community and includes the distribution of tasks between its members as well as status and power variables. Accordingly, rules, together with the division of labour, largely regulate how the tasks are carried out in the specific community.

According to Engeström (1999), these six elements interact with each other, and motives are generated through interactions, which in turn either facilitate or confine subjects'/agents' actions towards their goal (p. 381). Previous works within the academic reading field also suggest that all types of reading strategies, from cognitive to metacognitive and socio-effective are related to the learning environment of EFL/ESL students-readers. In other words, whether EFL/ESL students are able to enact reading strategies effectively depends both on cognitive factors and the environment they learn to read in English (Grabe \& Stoller, 2013).

\section{Method}

\subsection{Research Setting \& Participants}

This study was conducted at the school of marine engineering of the Merchant Marine Academy of Crete, a public tertiary institution located at the town of Chania, Greece. The four students were selected via purposive sampling (Stake, 2000) based on two professors' evaluations about their English reading difficulties. As the researcher was also the students' English teacher, she was aware these students faced difficulties with reading English texts for their core marine engineering courses and constantly avoided reading the assigned manuals and technical reports. Accordingly, she came into contact with these four students and asked them to participate in the study. Table 1 below introduces each of the participants. All four of them had received at least 9 years of formal education in English language both in state schools and in private foreign language schools.

Table 1. Background information about the participants

\begin{tabular}{lllll}
\hline Participant & Discipline & Origin & L1 & Age \\
\hline Participant 1 (P1) & Marine Engineering & Heraklion, Crete & Greek & 18 \\
Participant 2 (P2) & Marine Engineering & Athens & Greek & 18 \\
Participant 3 (P3) & Marine Engineering & Chania, Crete & Greek & 18 \\
Participant 4 (P4) & Marine Engineering & Heraklion, Crete & Greek & 19 \\
\hline
\end{tabular}




\subsection{Research Tools}

Individual semi-structured, interviews consisted the main research instrument of this study mainly because they provided a safe and comforting environment for the four participants who already had a low-self-esteem as a result of their poor English reading performance. I acknowledge however, that the interview is not a neutral research tool (Denzin \& Lincoln, 1998) and that it "produces situated understandings grounded in specific interactional episodes" (p. 36). In other words, I am aware that what participants shared with me during the interviews was influenced by the fact that they were sharing it with their teacher. If there were a different interviewer, a different rapport might have been produced. Since my main goal was to examine whether there was a change in participants' EFL reading approaches as a result of their transition between secondary and tertiary education, I decided I should have the interviews at the end of the winter semester, when participants would have acquired a clearer picture about the discipline-specific reading demands of their department. Accordingly, the interviews were held in February 2018, right the winter semester exams.

The interviews followed a set of questions (Appendix A) that aimed to explore participants' perceptions on the six elements of the activity system, but without expressing it openly. The questions focused on the participants' EFL reading backgrounds and histories, their perceived reading difficulties, their reading speed, their reading strategies and their attitude towards reading texts in English. Participants were encouraged to speak in Greek in order for them to be able to express themselves freely.

\subsection{Data Analysis}

Interview data were analyzed based on Engeström's (2014) activity system and explored the two systems students were a part of before and after entering the academy. The first system included the agents/subjects (the participants as EFL students in high school), their goals (personal goals, school goals), the tools (training in EFL reading etc.), rules (socio-cultural values, school requirements, parents requirements) and the division of labour (public school teachers, private school teachers and students). The second activity system included the system students became a part of after they entered the Merchant Marine Academy. It included the agents (current Greek undergraduate marine engineering students), their goals (personal goals combined with marine engineering school goals), tools (academic reading strategies etc.), rules (socio-cultural values and marine engineering school requirements), community (professors, lab assistants, English language teachers and other students) and finally division of labour (professors, lab assistants, the English language teachers and other students). The analysis investigated how these two activity systems were interconnected, affecting participants' approaches to reading discipline-specific texts in English. Data analysis included interview transcriptions and subsequent multiple readings with NVivo, a qualitative analysis software program that facilitates the identification of meaning units and themes across participants (Tesch, 2013).

\section{Results}

\subsection{Participants'EFL Reading Activity System Before Entering Tertiary Education}

Participants' backgrounds and prior English language learning experiences provided me with valuable data that shed light to their sociocultural context before they entered the Merchant Marine Academy. All of them had received 9 years of EFL instruction at the state school and except for P4, the other three students had received tuition in private foreign language schools and had multiple language certificates. P1's account is indicative of this theme:

"I started English at the third grade, then I took all sorts of exams for A1 and A2 certificates. These are not very serious, but everyone takes them." (P1)

Two participants had two language certificates for the B2 level, as the private foreign language schools in Greece recommended to them and their parents to take two exams in case they failed one of them:

"...I actually took two exams for two B2 certificates, just to make sure I would pass one of them. The school owner suggested it and my parents agreed". (P2)

Another common theme from participants' interviews was that all four of them stopped engaging in any type of English language learning, at least three years before entering the Merchant Marine Academy. Since there was no certificate-related motive after obtaining the B2, they focused on the next high-stake exam, that is, the national Panhellenic exams (Greek state exams for entering tertiary education). The in-school exams didn't seem to function as a motive for participants to study English:

“...after I took the FCE I stopped English. There was no time for English. I had to study for the Panhellenic exams, they are difficult...In general you have to finish with English before senior high-school...so 
basically now, I don't remember much." (P1)

“...I stopped reading or writing in English, around the 9th grade, when I passed the FCE exam ...I usually google Greek sources if I need something." (P2)

“...Last time I read something in English, was when I took the FCE, I think or maybe for the English exam at school, but I never studied for English at school, I literally read only the text that was in the exam or wrote an essay or a letter or something, I don't even remember." (P3)

This continuous preparation for language certificate exams at the private English language schools encouraged participants to adopt a passive approach to EFL reading mainly using careful. bottom-up reading strategies and translation:

“...We would read the text, then the teacher would ask us to translate the words we didn't know, or use the Companion a special book that had all the words translated in Greek and then find the correct answers and that was about it really." (P1)

Grammar also emerged as a theme in all participants' accounts when asked about their previous EFL reading experiences:

"It wasn't so much about reading...it was mostly grammar, because there's lots of grammar in the FCE exam, if you don't know grammar you will never pass the exam, so the teacher used to tell us which exercise to do and then we checked the answers together." (P2)

"...Grammar, like tenses when we use them, conditionals, that was really important, we learned the rules by heart and we also had a Greek grammar book so that we could understand it better." (P3)

P2 also used to learn vocabulary by heart from the "companion" book and he was then tested in translating the specific words in the next lesson:

"That was the worst part, at least for me, because we had to learn the words and then next time, we had to write them like a test with the Greek translation and the teacher would then check it." (P2)

Participants' overall EFL reading experiences and actions imply that prior to entering the Merchant Marine Academy they were mainly involved with exam preparation for B2-level language certificates. These exam-oriented actions, from an activity theory perspective form an activity which constitutes a part of a wider activity system relating to the foreign language education system in Greece (Appendix B: Figure 1). More specifically, the four participants who currently are marine engineering students, as secondary education students, were the subjects, who had a pressing goal to obtain a B2 certificate before senior high-school. In order to achieve this goal, they took a serious of preparation classes and tests. They first enrolled themselves in a private foreign language school. They then took a number of tests for different English language certificates for which they also took countless mock exams, they practiced specific bottom-up, linear reading strategies with short texts and lots of grammar and translation within a teacher-centered approach. After achieving their English-certificate object they ceased any attempt of engaging in English language learning, including reading. As a result, these students' English reading practice was limited and dated from three to five years before entering the Merchant Marine Academy.

\subsection{Participants' EFL Reading Activity System After Entering Tertiary Education}

After entering the merchant marine academy, participants' views on EFL reading shifted from being the "easiest skill" to the "hardest" and at the same time the most "useful". Instead of the easy and short tailor-made B2-level texts, participants realized that reading in marine engineering involves challenging genres and critical reading strategies:

“...I actually thought reading in English was easy, you know compared to writing, but here no, it isn't. Because the texts, I mean the real texts, not the English coursebook we have, are not like the ones we had for the FCE exam, all short and neat. They are really complicated and long packed with terminology and they are densely written, especially the manuals..." (P2)

When asked whether they thought they were adequately prepared for reading discipline-specific genres within their new community participants all seemed to agree they had no preparation whatsoever:

"All these readings, from textbooks to technical reports and the manuals, they are so long with difficult words and terminology nothing like what we did for the FCE". (P2)

Feelings of injustice also emerged as a theme, as two participants made references to the fact that on the one hand Maritime English is a challenging subject, but English is not a course required in the Panhellenic exams to 
be accepted in the specific school:

"It is unfair you know, English is not even a course required to enter this school in the Panhellenic exams... and then we come here and we have three hours of English, packed with new terminology for engines, pumps and so on and then other teachers ask us to read really long, difficult manuals and books in English. Not all of us had money to go to a private English Language school. I didn't." (P4)

P2 felt his reading difficulties are related to his reading speed and the number of students in the English class:

"I am a slow reader, in English, I need to read everything carefully, but in the English class we are thirty people and each one of us has a different reading speed, so I usually end up not reading what we are supposed to read". (P2)

P3 also thought that the number of students in the English class prohibited him from actively participating in the lesson and thought that Maritime English should include more authentic English manuals and textbooks:

“...It would be better if we were like ten people in the class, like we were at the private English school I was in high-school...now it's like a sort of lecture...it would be better if we actually worked in the English class with the books and the manuals the other professors give us to read in English...because the texts in our English coursebook are easy and short but the texts we will actually have to read here for the other course and later in the ship, are extremely difficult." (P4)

When asked about the strategies, participants employed in order to read the manuals and other discipline-specific genres in English participants seemed to resort to strategies they had learned at the private foreign language schools during high-school:

"Translation is the main strategy I use, Google translate mostly, but it doesn't always work, sometime it takes ages, especially with long and specialized texts like manuals." (P3)

Reading lengthy texts such as manuals caused high-levels of anxiety to P2 who opted for the avoidance strategy:

"When professors give us a really long text or when they send us a pdf in English and it is like ten pages. I just open it, have a look at the number of pages and just close it again." (P2)

Regarding technical manuals in particular, all four participants perceived them as the most difficult genre they had to deal with upon entering the academy:

“Authentic technical engine manuals are really long and I most probably wouldn't understand them in Greek let alone in English...they have difficult syntax, everything is difficult about them and they are totally different to the coursebooks for the FCE and the exercises we do in English here". (P2)

Compared to the other three participants, P1 seemed more confident about his EFL reading strategies with challenging genres such as the manuals. The specific student seems to have developed a metacognitive awareness regarding reading strategies required for online searching and reading marine engineering genres online:

"Last week, Professor D. asked me to find a specific manual online and find something for dual-fuel engines...I actually searched it and found it ... I tried not to worry about understanding every single word or using google translate all the time...I think that was my major problem, translating everything, like we did at the language school I used to go to". (P1)

\section{Discussion}

My findings seem to suggest that these four first-year students, were constantly mediated between what they had brought with them from high-school and what they were expected to do at the Merchant Marine Academy. The controversies between the two systems triggered struggles and feelings of anxiety leading to novel motives and personalized goals in EFL reading.

Participants' EFL reading difficulties and the strategies they enacted to overcome them, directly relate to the previous activity system they belonged as high-school students/ EFL learners in Greece. This system essentially refers to the "Greek EFL certificate culture" which has been dominating the foreign language educational system for more than 40 years with a "gigantic exam-oriented industry" which effectively dictates EFL course and materials design and most importantly it dominates English language teaching and learning methodologies (Tsagari, 2009).

Tsagari and Sifakis $(2014$, p. 213) call this phenomenon the "Greek EFL educational paradox" which includes a "lethargic state sector" and a "competitive private sector" which effectively captivates the interest from all the stakeholders involved including parents, teachers, private language school owners, examining bodies, materials 
designers and prepares learners for high-stakes proficiency examinations that are perceived to be linked to a successful professional career. In this system, Greek parents want their children to get jobs mainly in the public sector and in order to achieve this goal they pay for private foreign language schools who are thought to be much more effective than state schools. At the same time, teachers at private foreign language schools are under tremendous pressure to make sure their students obtain countless language certificates in a short period of time so they largely adopt teacher-centered methodologies that are considered more effective and less time consuming (Tsagari, 2005; Tsagari \& Sifakis, 2014). My findings further suggest that participants' previous reading experiences in the private language schools mostly revolved around test-taking strategies, such as finding the correct answer of a reading task that was usually based on a short text from a commercial EFL textbook tailor-made for the B2 exam. Additionally, my data suggest that these students were only aware of bottom-up and support strategies such as slow reading and translation and seem unaware of other expeditious, top-down reading strategies such as skimming, scanning and search reading that are of paramount importance for first-year undergraduate students (Weir et al., 2009).

All these exam preparation actions are a part of a more complex social context. The Greek sociocultural values produce rules that literally dominate the Greek foreign language education system at all levels: from the place where Greek students actually learn English (at the private foreign language schools rather than the public school), to the syllabus design (B2 syllabus-based design), the teaching objectives, and so on. The whole activity system then is directed towards the object, which essentially is obtaining many language certificates, the outcome however, is that after many years of formal EFL education in public and private foreign language schools, Greek students are still underprepared for reading discipline specific genres such as technical manuals, reports, research papers etc. To some extent then, it could be argued that the four participants represented a community which is made up of hundreds of Greek 1st-year undergraduate marine engineering students in merchant marine academies across Greece, who in the past all shared the goal of passing the FCE exam and experienced similar test-preparation actions and were governed by the same rules, division of labour and used the same tools in order to achieve this goal.

\section{Conclusion}

My findings seem to suggest that Greek $1^{\text {st }}$ year undergraduate marine engineering students struggle in reading authentic, discipline-specific genres such as manuals and technical reports partly due to the fact that these are demanding genres and partly because the students themselves are constantly mediated between two activity systems -the one they belonged as EFL students/readers in high-school and the one they belong now. The wider Greek foreign language education system seems to fail to prepare students to cope with the demands of EFL reading at the tertiary level. Moreover, my findings indicate that students' academic reading needs are not fulfilled with the current Maritime English course. This finding is in accordance with findings from previous works that have focused on the effectiveness of the EFL and English for Academic Purposes courses offered in the wider Greek higher education context and found that they do not correspond to the actual needs of Greek university students which in turn explains the low attendance rates (Kantaridou, 2004).

The main implication of this study, is that the Greek maritime educational system, similarly to universities should focus on readjusting current English courses and methodologies to fulfil the students' actual needs by using authentic materials and integrating reading strategy-based instruction that will eventually help students become independent and critical readers (Seiradakis \& Spantidakis, 2018b). Additionally, maritime English teachers, much like the teachers in universities should work in collaboration with the "discipline insiders" which in the case of merchant marine engineering schools include chief engineers and other engineering professors.

\section{Acknowledgments}

Heartfelt thanks go to the four participants from the school of marine engineering, of the Merchant Marine Academy of Crete, for their time, the peer-reviewers and the editor for their constructive and valuable suggestions.

\section{References}

Bitran, M., Zúñiga, D., \& Leiva, I. (2012). Reading Strategies used by Undergraduate Medical Students to Comprehend Scientific Publications. Medical Science Educator, 22(3), 147-150. https://doi.org/10.1007/BF03341779

Denzin, N. K., \& Lincoln, Y. S. (1998). Collecting and interpreting qualitative material. Thousand Oaks, CA: Sage.

Engeström, Y. (1999). Communication, discourse and activity. Communication Review, 3(1-2), 165-185. 
https://doi.org/10.1080/10714429909368577

Engeström, Y. (2014). Learning by expanding. Cambridge University Press. https://doi.org/10.1017/CBO9781139814744

Grabe, W. P., \& Stoller, F. L. (2013). Teaching and researching: Reading. Routledge. https://doi.org/10.1002/9781405198431.wbeal1174

Harklau, L. (2001). From high school to college: Student perspectives on literacy practices. Journal of Literacy Research, 33(1), 33-70. https://doi.org/10.1080/10862960109548102

Kantaridou, Z. (2004). Motivation \& Involvement in Learning English for Academic Purposes. Unpublished PhD Thesis, Department of English Language \& Literature, Aristotle University of Thessaloniki.

Liu, J. (2015). Reading transition in Chinese international students: Through the lens of activity system theory. Journal of English for Academic Purposes, 17, 1-11. https://doi.org/10.1016/j.jeap.2014.11.004

Murray, T. A. (2014). Teaching students to read the primary literature using POGIL activities. Biochemistry and Molecular Biology Education, 42(2), 165-173. https://doi.org/10.1002/bmb.20765

Seiradakis, E., \& Spantidakis, I. (2018a). Training undergraduate engineering students to read research articles: A qualitative think-aloud study (pp. 1208-1213). In 2018 IEEE Global Engineering Education (EDUCON). https://doi.org/10.1109/EDUCON.2018.8363367

Seiradakis, E., \& Spantidakis, I. (2018b). Online course design and materials development for teaching reading of research articles to EFL undergraduate students at a Greek technical university. Journal of Teaching English for Specific and Academic Purposes, 6(2), 285-296. https://doi.org/10.22190/JTESAP1802285S

Shen, M. Y. (2013). Toward an Understanding of Technical University EFL Learners' Academic Reading Difficulties, Strategies, and Needs. Electronic Journal of Foreign Language Teaching, 10(1).

Spantidakis, I (2010). Socio-Cognitive Multimedia Environments for Learning and the Production of Writing. Athens: Gutenberg.

Spector-Cohen, E., Kirschner, M., \& Wexler, C. (2001). Designing EAP reading courses at the university level. English for Specific Purposes, 20(4), 367-386. https://doi.org/10.1016/S0889-4906(00)00019-3

Stake, R. E. (2000). Case studies. In N. K. Denzin \& Y. S. Lincoln (Eds.), Handbook of qualitative research (2nd ed., pp. 435-454). Thousand Oaks, CA: Sage.

Tesch, R. (2013). Qualitative research: Analysis types and software. Routledge. https://doi.org/10.4324/9781315067339

Tsagari, D. (2006). Investigating the washback effect of a high-stakes EFL exam in the Greek context: Participants' perceptions, material design and classroom applications. Doctoral dissertation, Lancaster University.

Tsagari, D. (2009). The Complexity of Test Washback: An Empirical Study. Frankfurt am Main, Peter Lang $\mathrm{GmbH}$.

Tsagari, D., \& Sifakis, N. C. (2014). EFL course book evaluation in Greek primary schools: Views from teachers and authors. System, 45, 211-226. https://doi.org/10.1016/j.system.2014.04.001

Weir, C., Hawkey, R., Green, A., Unaldi, A., \& Devi, S. (2009). The relationship between the academic reading construct as measured by IELTS and the reading experiences of students in their first year of study at a British university (Vol. 9, p. 97). International English Language Testing System (IELTS) Research Reports, 2009.

\section{Appendix A}

\section{Interview Questions}

1) Have you been taught how to read in English before you come here?

2) Where and how did you learn reading in English?

3) What are the main English reading difficulties you face now that you are a student here?

4) Do you think you were adequately prepared for reading English marine engineering texts?

5) Can you tell me the core differences between your English reading approach in high-school and what you are 
doing now?

6) What are the main difficulties you face here regarding reading coursework in English?

7) What is your reading speed in English? Has it changed since you entered the Merchant Marine Academy?

8) Has your reading approach changed over the last three months you study at the Merchant Marine Academy?

9) When you face a difficulty as you read an English text, do you take any actions so that you can comprehend more effectively? Where did you learn these strategies?

10) Has the English course here helped you with the coursework reading of the core marine engineering courses? If yes Why? If not why?

\section{Appendix B}

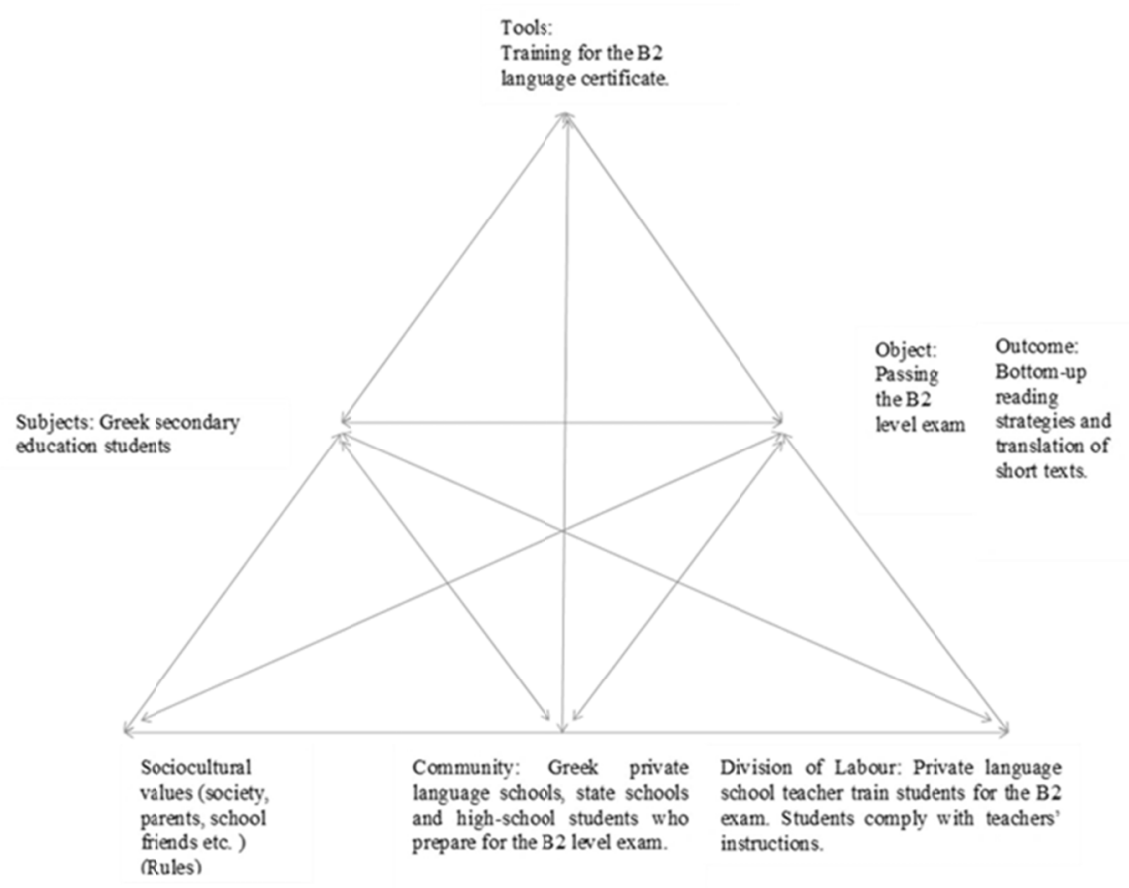

Figure 1. Participants' activity system before entering tertiary education

\section{Copyrights}

Copyright for this article is retained by the author, with first publication rights granted to the journal.

This is an open-access article distributed under the terms and conditions of the Creative Commons Attribution license (http://creativecommons.org/licenses/by/4.0/). 